\section{Michigan Technological \\ 18 8 5 University}

Michigan Technological University Digital Commons @ Michigan Tech

Global Conference of the Youth Environmental Alliance in Higher Education

Dec 9th, 2:00 PM - 2:11 PM

\title{
Session 1E Institutionalization of Climate Finance in the Green Climate Fund
}

Leo Banks

Follow this and additional works at: https://digitalcommons.mtu.edu/yeah-conference

\section{Recommended Citation}

Banks, Leo, "Session 1E Institutionalization of Climate Finance in the Green Climate Fund" (2020). Global Conference of the Youth Environmental Alliance in Higher Education. 19.

https://doi.org/10.37099/mtu.dc.yeah-conference/2020/all-events/19 


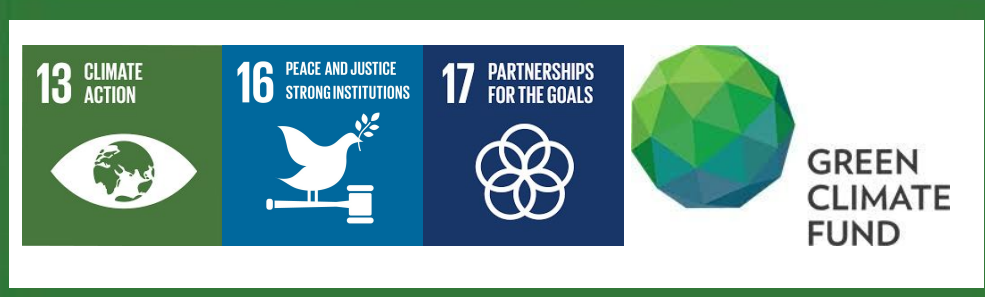

\section{Background:}

\section{Institutional Structure}

- $\quad$ Board: 24 members divided equally between developed and developing countries \& according to regional representation.

- Secretariat:Manage the day to day activities of the fund.

- The GCF is accountable to the UNFCCC and receives guidance from the COP

- $\quad$ Country ownership approach

- $\quad$ Trusteeship delegated to the World Bank

\section{Functional Structure}

- 50/50 Funding split between mitigation and adaptation. ${ }^{1}$

Accreditation:

- To apply for funding an entity must be accredited

- Two types of accredited entities:

- International access entities

Direct access entities

- International access entities:

- International financial institutions

World Bank, ADB, etc.

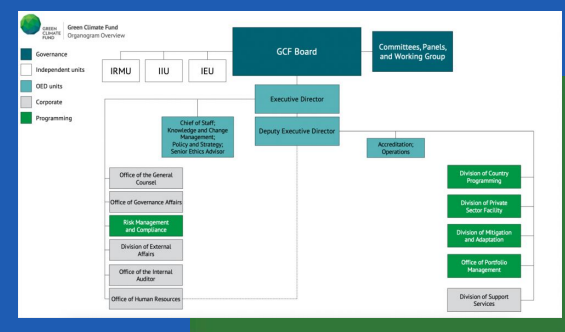

Direct access entities

National and sub national entities

National ministries, regional governments, etc.

Must be nominated by an National Designated Authority (NDA) Non accredited entities may access funding through an accredited entity Accreditation process is long and technically rigorous process, applicant

entity must meet a variety of fiduciary, environmental, and social standards

- Board has final say on accreditation under advice from the independent

accreditation panel

- The board meets three times a year and meetings are often attended by

over 300 people

- Board meetings take the style of international climate negotiations (most members are government ministers) rather than a traditional corporate board. $^{2}$

\section{Initial Conflict}

During the initial negotiation

of the GCF, particularly after

the report of the transitional

committee at COPs 16 and

17 , there was significant

would be accountable to the

UNFCCC. Developing

countries argued for a

looser relationship while

developed argued for direct

accountability with the later

eventually prevailing. disagreement over the

extent to which the Fund
Capacity Building \& the Importance of

Institutions

The GCF, like all

international financial

institutions, is a highly

technocratic entity that

draws on vast expertise in

its day to day operations. As

such applying for

accreditation or funding is a

daunting process that

requires significant

institutional capacity. ${ }^{4}$ The

GCF recognizes this and

through the secretariat,

provides assistance in the

accreditation process. ${ }^{5}$

However, while this goes

some way to addressing

issues of inadequate

capacity it does not alleviate

them entirely.
For areas that are affected by significant governmental instability such as those in conflict zones, the documentation required to become accredited is likely non existent. This is an area where international access entities highly useful but it inevitably creates delays in getting funding to areas that are perhaps the most vulnerable. Thus the role of international access institutions becomes one of more than just climate financer as they have a role in shaping nationa and sub national institutions such that they may eventually be direct access entities. ${ }^{6}$
Notable Sources

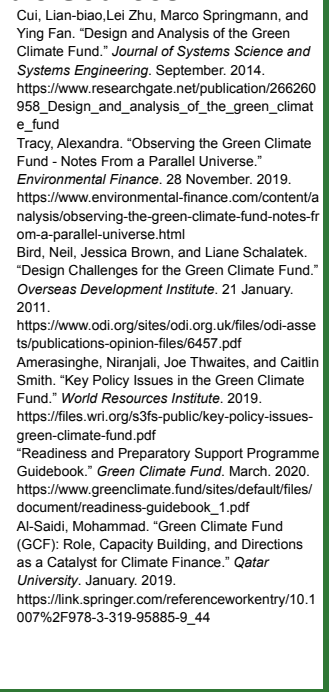

